\title{
Organic acid enhanced electrodialytic extraction of lead from contaminated soil fines in suspension
}

Jensen, Pernille Erland; Ahring, Birgitte Kiær; Ottosen, Lisbeth M.

Published in:

Journal of Chemical Technology and Biotechnology

Link to article, DOI:

10.1002/jctb.1762

Publication date:

2007

Link back to DTU Orbit

Citation (APA):

Jensen, P. E., Ahring, B. K., \& Ottosen, L. M. (2007). Organic acid enhanced electrodialytic extraction of lead from contaminated soil fines in suspension. Journal of Chemical Technology and Biotechnology, 82(10), $920-$ 928. https://doi.org/10.1002/jctb.1762

\section{General rights}

Copyright and moral rights for the publications made accessible in the public portal are retained by the authors and/or other copyright owners and it is a condition of accessing publications that users recognise and abide by the legal requirements associated with these rights.

- Users may download and print one copy of any publication from the public portal for the purpose of private study or research.

- You may not further distribute the material or use it for any profit-making activity or commercial gain

- You may freely distribute the URL identifying the publication in the public portal 


\title{
Organic acid enhanced electrodialytic extraction of
}

\section{lead from contaminated soil fines in suspension}

\author{
Pernille E Jensen ${ }^{\mathrm{a} *}$, Birgitte K Ahring ${ }^{\mathrm{b}}$ and Lisbeth M Ottosen ${ }^{\mathrm{a}}$
}

${ }^{a}$ Department of Civil Engineering, Kemitorvet, Building 204, Technical University of Denmark, 2800 Lyngby, Denmark.

${ }^{\mathrm{b}}$ BiC Biocentrum, Building 227, Technical University of Denmark, 2800 Lyngby, Denmark.

*Correspondence to: Pernille E Jensen, Department of Civil Engineering, Kemitorvet, Building 204, Technical University of Denmark, 2800 Lyngby, Denmark

E-mail: pej@byg.dtu.dk; Phone: +45 45252255; Fax: +45 45885935

\begin{abstract}
:
Implementation of the soil washing technology for the treatment of heavy metal contaminated soils is limited by the toxicity and unwieldiness of the remaining heavy metal contaminated sludge. In this work, we investigated the feasibility of combining electrodialytic remediation with heterotrophic leaching for decontamination of the sludge. The ability of 11 organic acids to extract $\mathrm{Pb}$ from the fine fraction of contaminated soil (grains $<63 \mu \mathrm{m}$ ) was investigated, and application of the acids as enhancing reagents during electrodialytic remediation (EDR) of $\mathrm{Pb}$-contaminated soil fines in suspension was tested. Five of the acids showed ability to extract $\mathrm{Pb}$ from the
\end{abstract}


soil fines in excess of the effect caused solely by $\mathrm{pH}$-changes. Addition of the acids, however, severely impeded EDR, hence promotion of EDR by combination with heterotrophic leaching was rejected. In contrast, enhancement of EDR with nitric acid gave promising results.

Keywords: electrodialysis; electrokinetic; heterotrophic leaching; organic acid; remediation; soil washing.

\section{INTRODUCTION}

Electrodialytic soil remediation (EDR) is an electrokinetic remediation (EKR) method, in which ion-exchange membranes are applied as barriers between soil and electrolytes. In order to solve an essential waste-problem of the remaining sludge after soil-washing, EDR of soil fines in suspension has been suggested as a potential treatment method. ${ }^{1}$ Prior to treatment, the sludge contains the bulk of the contaminants washed out of the coarser fractions. In addition, the sludge has a high water-content (commonly up to 95\%), and due to its surface properties, it is not easily dewatered. Thus soil washing, although successfully and efficiently implemented, produces not only a considerable fraction of cleaned materials, but also a significant volume of relatively more toxic material which is difficult to handle and not easily disposed of. The aim of the present work was to investigate the enhancement of the EDR process, already documented, ${ }^{1}$ for the improved treatment of $\mathrm{Pb}$-contaminated sludge by addition of a suiting enhancing reagent. 


\section{Enhancing reagents}

The efficiency of various reagents for extraction of $\mathrm{Pb}$ and other heavy metals from soil during soil wash has been extensively investigated. The strong chelating agent ethylenediaminetetraacetic acid (EDTA) has been repeatedly and successfully tested. ${ }^{2-}$

${ }^{4}$ Its suitability has, however, been questioned because of its low biodegradability and potential hazard to the environment. ${ }^{5,6}$ Similarly, enhancement of EKR with EDTA is well documented, ${ }^{7-9}$ with the important note that although the extraction of $\mathrm{Pb}$ from soil by EDTA was shown to be $\mathrm{pH}$-independent, ${ }^{10}$ enhancement of EKR was obtained only at $\mathrm{pH}$ values above $5 .{ }^{9}$ Chelating agents more susceptible to biodegradation such as [s,s]-ethylenediaminedisuccinic acid (EDDS) and nitrilotriacetic acid (NTA) extracted $\mathrm{Pb}$ less efficiently than EDTA due to a much stronger complexation of $\mathrm{Pb}$ by EDTA. ${ }^{11}$

Besides chelating agents, organic acids possess potential to extract heavy-metals due to their complexing behaviour. In contrast to EDTA, extraction of $\mathrm{Pb}$ from soil by organic acids and their ammonium-salts was shown to be highly $\mathrm{pH}$-dependent, ${ }^{10}$ but in the $\mathrm{pH}$ range $2-7$ citrate $(0.2 \mathrm{M})$ and tartarate $(0.5 \mathrm{M})$ extracted $\mathrm{Pb}$ as efficiently as EDTA. In addition, the organic acids were shown to act more gentle towards the soil by removing $80 \%$ less macronutrients $(\mathrm{Ca}, \mathrm{Mg}, \mathrm{Fe})$ compared to $\mathrm{EDTA}^{10}$ In accordance, a substantial improvement of EKR of $\mathrm{Pb}$ from a spiked silt loam was demonstrated after citric acid addition at $\mathrm{pH}$ values between 3.3 and $5.4,{ }^{12}$ while EDR of $\mathrm{Pb}$ from municipal solid waste incineration (MSWI) fly ash was enhanced by addition of sodium citrate ${ }^{13}$ and ammonium citrate ${ }^{14}$ at alkaline $\mathrm{pH}$ values. Although 
acetate was shown to be a moderate extractant of $\mathrm{Pb}$ from soil, ${ }^{10}$ several authors reported on the successful enhancement of EKR by acetic acid at low $\mathrm{pH},{ }^{7,12,15,16}$ however, less efficiently than by citric acid. ${ }^{12}$

Altogether current knowledge supports the feasibility of enhancing EKR/EDR of soil by addition of either chelating agents or organic acids. The fact that biodegradable organic acids were shown to extract $\mathrm{Pb}$ as efficiently as the persistent EDTA, encourages the use of organic acids, such as citric acid and tartaric acid.

\section{Heterotrophic leaching}

Several authors suggested leaching by heterotrophic bacteria or fungi as an economical alternative method of extraction of valuable metals from non-sulfide, lowgrade ores in the mining industry. ${ }^{17-19}$ The technique is based upon the ability of selected microorganisms to produce organic acids during growth, and their potential growth on cheap organic waste-products. Heterotrophic leaching was later suggested for treatment of industrial wastes, sewage sludge and heavy metal contaminated soil. ${ }^{20-22}$ Most research within the heterotrophic leaching of contaminated materials was conducted with fly ash. It was shown that Aspergillus niger grew and produced gluconate in the presence of $10 \%(\mathrm{w} / \mathrm{v})$ fly ash, while citrate was produced in its absence. Chemical leaching with commercial citric acid was only slightly higher than microbiological leaching. ${ }^{23}$ In another study Penicillium simplicissimum was shown to produce citric acid in the presence of $\mathrm{Zn}$-contaminated filter dust while no acid production was seen in its absence, ${ }^{24}$ and it was shown how extraction of $\mathrm{Pb}$ from 
filter dust by yeasts isolated from seeping water, waste compost, and sewage was possible. ${ }^{25}$ These studies suggest that growth and acid production would also take place in the presence of heavy-metal contaminated soil fines. The idea that microbial extraction of even very stabile $\mathrm{Pb}$-compounds is possible, was suggested by Sayer et al., who observed growth of $A$. niger with pyromorphite as sole phosphate source. ${ }^{26}$ In addition, it was shown that application of direct current increased the metabolism of bacteria in soil slurries ${ }^{27}$ which supports the feasibility of heterotrophic leaching in combination with EDR/EKR.

In the present work, the feasibility of a new approach, in which combination of heterotrophic leaching and EDR of $\mathrm{Pb}$ contaminated soil fines in suspension, is studied. The aim of this technique is to induce production of organic ligands by heterotrophic organisms for complexation and mobilization of $\mathrm{Pb}$ prior to or simultaneously with removal of charged ligand- $\mathrm{Pb}$ complexes by EDR. Positive side effects such as mobilization of nutrients for increased heterotrophic leaching could be expected. The potential of the technology depends on the ability of organic acids to enhance $\mathrm{EDR}$ of $\mathrm{Pb}$ from soil fines. Our research comprises batch extraction experiments with 11 organic acids at neutral to slightly acidic $\mathrm{pH}$, where acid producing fungi grow, and an experimental evaluation of the effect of addition of selected organic acids on EDR. The acids were all chose as naturally produced products of heterotrophic microorganisms. ${ }^{21}$ 


\section{MATERIALS AND METHODS}

Soil: An industrially contaminated Danish soil was used for the experiments. The soil fines were obtained by wet-sieving of the original soil with distilled water through a $0.063 \mathrm{~mm}$ sieve. Concentrated slurry of fines was obtained by centrifugation at 3000 rpm for 10 min and decantation of the supernatant. The soil fines were kept as a slurry and stored at $5^{\circ} \mathrm{C}$ in access of oxygen. The metal content ( $\left.\mathrm{Fe}, \mathrm{Mn}, \mathrm{Al}, \mathrm{Pb}\right)$ was determined by atomic absorption spectrophotometry (AAS). Prior to analysis of soil

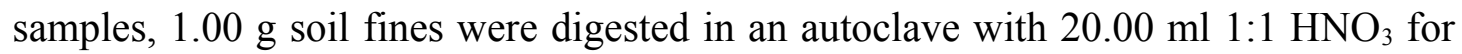
30 min at $120^{\circ} \mathrm{C}$ and $200 \mathrm{kPa}$ according to the Danish standard method DS259, ${ }^{28}$ and filtered through a $0.45 \mu \mathrm{m}$ filter by vacuum. Liquid samples with $\mathrm{pH}>4$ were preserved by digestion with concentrated $\mathrm{HNO}_{3}(1: 4)$. Validation of AAS results for all metals was obtained by measurement against liquid reference samples. The carbonate content was determined volumetrically by the Scheibler-method after reacting $3 \mathrm{~g}$ of soil with $20 \mathrm{ml}$ of $10 \% \mathrm{HCl}$. For calculations it was assumed that all carbonate was present as calcium-carbonate. Organic matter was determined by loss of ignition at $550^{\circ} \mathrm{C}$ for one hour. The Cation Exchange Capacity (CEC) was analyzed by a method comparable to the acid- $\mathrm{NaCl}$ method described in EPA Standard Method 9080 including ion exchange of $10 \mathrm{~g}$ dry soil with $\mathrm{NH}_{4}{ }^{+}$, followed by exchange of $\mathrm{NH}_{4}^{+}$for $\mathrm{Na}^{+}$. The ammonium concentration of the centrifugate was measured via flow-injection spectrophotometry. For pH-measurements $5.0 \mathrm{~g}$ dry soil was shaken with $12.5 \mathrm{ml} 1 \mathrm{M} \mathrm{KCl}$ for one hour followed by settling for $10 \mathrm{~min}$ and measurement by a Radiometer Analytical ion selective electrode. Sequential extraction was 
performed according to the method from the Standards, Measurements and Testing Program of the European Union: ${ }^{29} 0.5 \mathrm{~g}$ of dry, crushed soil was treated in four steps as follows:

1) Extraction with $20.0 \mathrm{ml} 0.11 \mathrm{M}$ acetic acid $\mathrm{pH} 3$ for 16 hours;

2) Extraction with $20.0 \mathrm{ml} 0.1 \mathrm{M} \mathrm{NH} \mathrm{NH}_{2} \mathrm{OH} \cdot \mathrm{HCl} \mathrm{pH} 2$ for 16 hours;

3) Extraction with $5.0 \mathrm{ml} 8.8 \mathrm{M} \mathrm{H}_{2} \mathrm{O}_{2}$ for one hour and heating to $85^{\circ} \mathrm{C}$ for one hour with lid followed by evaporation of the liquid phase at $85^{\circ} \mathrm{C}$ until it had reduced to $<$ $1 \mathrm{ml}$ by removal of the lid. The addition of $5.0 \mathrm{ml} 8.8 \mathrm{M} \mathrm{H}_{2} \mathrm{O}_{2}$ was repeated followed by heating to $85^{\circ} \mathrm{C}$ for one hour and removal of the lid for evaporation until almost dry. After cooling, $25.0 \mathrm{ml} 1 \mathrm{M} \mathrm{NH} \mathrm{NOCCH}_{3} \mathrm{pH} 2$ was added, and extraction took place for 16 hours.

4) Finally digestion according to DS 259 was made for identification of the residual fraction. Between each step the sample was centrifuged at $3000 \mathrm{rpm}$ for $15 \mathrm{~min}$, and the supernatant was decanted and stored for AAS.

Before addition of the new reagent, the sample was washed with $10.0 \mathrm{ml}$ distilled water for $15 \mathrm{~min}$, centrifuged at $3000 \mathrm{rpm}$ for $15 \mathrm{~min}$ and the supernatant decanted. All extractions were performed at room temperature under shaking at 100rpm unless otherwise mentioned.

All analyses were made in triplicate except CEC and sequential extraction, which were duplicated. 
Extraction experiments: Soil fines $(5.00 \mathrm{~g})$ were allowed to equilibrate with $25 \mathrm{ml}$ reagent at room temperature for 7 days while shaken at $180 \mathrm{rpm}$. Metal content and $\mathrm{pH}$ were measured on the liquid phase. $\mathrm{HNO}_{3}$ extractions were made at concentrations between 0.01 and $2 \mathrm{M}$. Organic acids (acetic acid, citric acid, DL-malic acid, formic acid, fumaric acid, gluconic acid, lactic acid, L-glutamic acid, oxalic acid, pyruvic acid, tartaric acid) were all used at $0.2 \mathrm{M}$ concentration and adjusted to $\mathrm{pH}$ values of 2, 3, 4 and 5 with $\mathrm{HNO}_{3} / \mathrm{NaOH}$. Citric and DL-malic acids were chosen for further study, and prepared in concentrations between $0.2 \mathrm{M}$ and $1 \mathrm{M}$ at $\mathrm{pH}$ values of 5 and 6 prior to extraction in accordance with the described procedure. All extractions were made in duplicate.

Remediation experiments: Electrodialysis experiments were made in cylindrical Plexiglas-cells with three compartments (Figure 1). Compartment II, which contained the soil-slurry was $10 \mathrm{~cm}$ long and $8 \mathrm{~cm}$ inner diameter. The slurry was kept in suspension by constant stirring with plastic-flaps attached to a glass-stick and connected to an overhead stirrer (RW11 basic from IKA). The anolyte was separated from the soil specimen by an anion-exchange membrane, and the catholyte was separated from the soil specimen by a cation-exchange membrane. Both membranes were obtained from Ionics ${ }^{\circledR}$ (types AR204SZRA and CR67 HVY HMR427). Electrolytes were circulated by mechanical pumps (Totton Pumps Class E BS5000 Pt 11) between electrolyte compartments and glass bottles. Platinum coated rod electrodes (surface area approximately $3 \mathrm{~cm}^{3}$ ) from Permascand ${ }^{\circledR}$ were used as working electrodes, and the power supply was a Hewlett Packard® E3612A. The 
inter-electrode gap was $14 \mathrm{~cm}$. The electrolytes (compartment I and III) initially consisted of each $500 \mathrm{ml} 0.01 \mathrm{M} \mathrm{NaNO}_{3}$ adjusted to $\mathrm{pH} 2$ with $\mathrm{HNO}_{3}$. Conductivity in compartment II, $\mathrm{pH}$ in all compartments, and voltage between the working electrodes were observed approximately once every 24 hours. The electrolyte $\mathrm{pH}$ was adjusted and maintained between 1 and 2 by manual addition of $\mathrm{HNO}_{3} / \mathrm{NaOH}$. Experiments were made according to the experimental plan (Table 1). All experiments lasted 240 hours and were designed with a liquid-to-solid-ratio (L/S) of 10.5 (37g soil, $390 \mathrm{ml}$ liquid). The $\mathrm{pH}$ of malic and citric acid solutions was adjusted with $\mathrm{NaOH}$. In the last three experiments (MA40N, CA40N and KC40) the reagent was allowed to react with the soil fines for 24 hours prior to application of the current. In four of the experiments (MA20N, CA20N, MA40N, CA40N) compartment II was kept at pH 6 by manual addition of $\mathrm{NaOH}$.

After each experiment, membranes were cleaned overnight in $1 \mathrm{M} \mathrm{HNO}_{3}$, and electrodes were cleaned overnight in $5 \mathrm{M} \mathrm{HNO}_{3}$. Volumes of the cleaning acids, the electrolytes, and the solution in the middle compartment were measured followed by analysis of the cation-concentrations by AAS. The remaining soil mass was determined and the $\mathrm{Pb}$ concentration in the soil measured by AAS after digestion according to DS259 as described above. The mass balance for $\mathrm{Pb}$ was calculated as the mass of $\mathrm{Pb}$ found in the whole system after remediation (in soil, soil solution, electrolytes, membranes, and at electrodes) as a percentage of the total amount found in the soil prior to remediation. The current efficiency is defined, and was calculated as the fraction of the current passing through an electrolytic cell that accomplishes a 
specific chemical reaction (in this case transfer of $\mathrm{Pb}$ from the soil fines into the electrolyte). The current efficiency of the $\mathrm{Pb}$ removal was calculated as follows:

$$
\varepsilon_{P b}=\frac{Q_{P b}}{Q_{t o t}}=\frac{\left(M_{P b} \cdot z_{P b} / M W_{P b}\right)}{(I \cdot t / F)}
$$

where $Q_{P b}$ is the amount of current (moles) transferred by $\mathrm{Pb}^{2+}$, and $Q_{t o t}$ is the total amount of current passed through the cell during remediation. $M_{P b}$ is the mass of $\mathrm{Pb}$ transferred from the soil fines, $z_{P b}$ is the valence of the species $\mathrm{Pb}$ (i.e. $2+$ ), $M W_{P b}$ is the molar weight of $\mathrm{Pb}$. I is the current (in A) passed through the cell, $\mathrm{t}$ is the experimental time (in seconds), and $\mathrm{F}$ is the Faraday constant.

\section{RESULTS}

Soil characteristics: The characteristics of the soil fines are listed in Table $2 . \mathrm{Pb}$ was analyzed in triplicate for each batch of soil-fines. The soil is carbonaceous and has a significant content of organic matter. Three different batches were used in the present work containing between 670 and $1170 \mathrm{mg} / \mathrm{kg} \mathrm{Pb}$. Sequential extraction (Figure 2) shows how $\mathrm{Fe}$ and $\mathrm{Al}$ are more strongly bound in the soil than $\mathrm{Pb}$ and in particular $\mathrm{Mn}$.

Extraction experiments: The ability of 10 of the organic acids to extract $\mathrm{Pb}$ is illustrated in Figure 3. Extraction results with oxalic acid are not shown because the final $\mathrm{pH}$ of the slurry was above 7 . The maximum extraction of $\mathrm{Pb}$ with oxalic acid 
was $1 \%$ obtained at $\mathrm{pH} 9-10$. Six of the acids showed similar or worse extraction results than $\mathrm{HNO}_{3}$ in this slightly acidic to neutral $\mathrm{pH}$ interval (pH 3-7), while five of the acids (citric acid, DL-malic acid, gluconic acid, tartaric acid and fumaric acid) showed pronounced improvement at near neutral $\mathrm{pH}$ probably due to complexation between $\mathrm{Pb}$ and the organic ligands of the acids. The best extraction was obtained with citric and malic acids. Citric acid extracted $22 \%$ of the $\mathrm{Pb}$ at $\mathrm{pH} 7.2$, while DLmalic acid extracted $11 \%$ of the $\mathrm{Pb}$ at $\mathrm{pH}$ 6.8-7.1 (initial $\mathrm{pH}$ of extractants 5.0).

Based on these results, the effect of increased extractant concentrations on the extractability of $\mathrm{Pb}, \mathrm{Fe}, \mathrm{Mn}$ and $\mathrm{Al}$ by citric and DL-malic acids was investigated (Figure 4). Increased extraction of $\mathrm{Pb}$ and the natural soil cations $\mathrm{Fe}, \mathrm{Mn}$ and $\mathrm{Al}$ was obtained by increasing the concentration of both citric acid and DL-malic acid. However, at the highest concentration of citrate acid $(1 \mathrm{M})$ a significantly decrease in extraction of all investigated elements was observed. This could be due to precipitation of the complexes formed. The best extraction of $\mathrm{Pb}$ was obtained with 0.4 and $0.6 \mathrm{M}$ citrate and $1.0 \mathrm{M}$ malate, which extracted equivalent amounts of all metals including $35 \%$ of the $\mathrm{Pb}$.

Remediation experiments: Based on the results of the extraction experiments, it was decided to perform EDR experiments with citric and malic acids as reagents. Reference experiments were made with distilled water and nitric acid. The main results of the 10 EDR experiments are summarized in Table 3. Mass balances for $\mathrm{Pb}$ between 61 and 115\% were obtained. Although the low mass balances in some of the experiments mean that interpretation of the data should be made with caution, the 
results of the experiments were significant enough to draw conclusions. The $\mathrm{Pb}$ concentrations in the soil-fines post treatment obtained were between 40 and 980 $\mathrm{mg} / \mathrm{kg}$. In some of the experiments a considerable amount of the released $\mathrm{Pb}$ remained in the solution in compartment II (up to 55\%), while in other experiments all the released $\mathrm{Pb}$ was transported into the electrolytes. Between 0.05 and $2.31 \%$ of the current transferred $\mathrm{Pb}$-ions out of compartment II (calculated as the \%o of the total transferred charges carried by $\mathrm{Pb}^{2+}$ into the electrolytes).

The first four experiments (DW20, MA20, CA20, NA20) were run under identical conditions except for the reagent in which the soil fines were suspended. From Table 3 it can be seen that the lowest final $\mathrm{Pb}$-concentration in the soil fines was obtained in the experiment with nitric acid (NA20), followed by the experiment with distilled water (DW20), while less successful remediation was obtained in the experiments with malic acid (MA20) and citric acid (CA20). The distribution of $\mathrm{Pb}$ in the remediation cell after experimental remediation is given for all experiments in Figure 5. Here it can be seen that the removed $\mathrm{Pb}$ was successfully transferred out of compartment II and into compartment III in the experiment with distilled water, while a large fraction of the $\mathrm{Pb}$ remained in the solution in compartment II in the experiments with nitric acid and malic acid. Almost all the $\mathrm{Pb}$ remained bound to the soil particles in the experiment with citric acid. The higher Pb-transport out of compartment II in the experiment with distilled water is reflected by a higher current efficiency (Table 3) in this experiment. The overall result of these four experiments is that distilled water is superior for EDR of $\mathrm{Pb}$-contaminated soil-fines in suspension. 
The $\mathrm{pH}$-development in the middle compartment (II) during the first four electrodialytic remediation experiments (DW20, MA20, CA20, NA20) is illustrated in Figure 6. This figure shows how the $\mathrm{pH}$ decreased in the experiment with distilled water as expected. ${ }^{1}$ The $\mathrm{pH}$ in the experiment with nitric acid was initially slightly lower than in the experiment with distilled water; however, it increased during the first 80 hours to reach values similar to the distilled-water experiment. The $\mathrm{pH}$ in the organic acid experiments decreased slowly throughout the experimental period to reach a final $\mathrm{pH}$ of approximately 4.5 .

Because the extraction experiments showed that $\mathrm{Pb}$ was more efficiently extracted at near neutral $\mathrm{pH}$ with the organic acids, experiments were made to show if the $\mathrm{pH}$-drop in experiments MA20 and CA20 was responsible for the reduced remediation when adding these acids. In the following two experiments (MA20N and CA20N) the $\mathrm{pH}$ was kept between 6 and 7 in compartment II throughout the experiment. The results in Table 4 show that keeping the $\mathrm{pH}$ neutral worsened the result of remediation with malic acid slightly, while citric acid was more efficient, although still less efficient than either distilled water or nitric acid. Hence the $\mathrm{pH}$-drop was not solely responsible for the reduced remediation.

The conductivity of the soil solution in the first four experiments (Figure 7) was directly related to the concentration of added acid. The highest conductivity was seen in MA20, in which 1M malic acid was added. Compared to this, the conductivity was about half in CA20, in which $0.5 \mathrm{M}$ citric acid was added. The initial conductivity was only slightly elevated in NA20 with nitric acid (pH 1.4) compared to DW20, and by the end of the experiments, the conductivity had increased in DW20 beyond that of 
NA20. The conductivity decreased constantly in the organic acid experiments, because organic ligands were transferred out of the soil solution. This transport was confirmed by visible inspection of CA20, in which the anolyte turned yellow after only 24 hours with a clear intensification of the colour during the experimental period.

The fact that the conductivity was substantially higher in MA20 and CA20 compared to DW20, suggested that the current density in these experiments could be increased beyond what is ideal for remediation with distilled water. It was shown in a previous study that $20 \mathrm{~mA}$ is the optimal current density for EDR of soil fines in suspension at L/S 10.5 with distilled water as reagent. ${ }^{1}$

This hypothesis was tested by increasing current to $40 \mathrm{~mA}$ in experiments with malic acid and citric acid (MA40N and CA40N). In addition, additional experiments with nitric acid (NA40), and potassium citrate $(\mathrm{KC} 40)$ at increased current densities were made. Potassium citrate was chosen because it required a large amount of $\mathrm{NaOH}$ to adjust the organic acids to near neutral values, and addition of the salts of the acids seemed more practical. In NA40 the concentration of nitric acid was increased compared to the concentration in NA20 to exceed the buffer capacity of the soil and increase the conductivity sufficiently to enable application of the higher current without induction of water splitting at the cation-exchange membrane. ${ }^{1}$ In addition, the reagents were allowed to react with the soil fines for 24 hours prior to application of the current to make sure that the lack of remediation success with the organic acids was not due to insufficient reaction time to form complexes between $\mathrm{Pb}$ and the organic ligands. 
From the results in Table 3 it is seen that the increased current seems to have no or even adverse effects on the remediation with malic acid. In the experiment with citric acid, increased current density seemed to have a positive influence on extraction and transfer of $\mathrm{Pb}$ into the anolyte, however, by no means reaching the efficiency of EDR with distilled water. Addition of potassium citrate strongly impeded remediation compared to all other experiments even the ones with citric acid. Thus too low a current density or too little time to react could also not explain the low remediation with malic and citric acids as reagents. The best results were obtained with increased current $\left(0.8 \mathrm{~mA} / \mathrm{cm}^{2}\right)$ and addition of $0.5 \mathrm{M}$ nitric acid (NA40). Here $90 \%$ of the $\mathrm{Pb}$ was removed from the soil, $81 \%$ of the $\mathrm{Pb}$ had been transferred to the cathode/catholyte, and the final $\mathrm{Pb}$ concentration was $40 \mathrm{mg} / \mathrm{kg}$, which is exactly the limiting value set by the Danish authorities for clean soil.

\section{DISCUSSION}

Extraction experiments: The promising $\mathrm{Pb}$-extracting properties of citrate, tartarate and malic acid are consistent with previous findings, ${ }^{10,30}$ although the previous works reported substantially higher extraction than what was found in the present work. The discrepancy may be due to the 5 times higher liquid-to-solid ratio and the more coarse grained material used in the previous studies. ${ }^{10}$ It may also be linked to the high carbonate content of the present soil, or possibly the presence of less soluble $\mathrm{Pb}$ compounds. The fact that the $\mathrm{pH}$ of the soil increased after addition of oxalic acid at $\mathrm{pH}$ values $2-5$, well below the initial soil $\mathrm{pH}$, indicates a complex interaction between soil constituents and oxalate, which may include dissolution of iron oxides and 
hydroxides resulting in the observed increase in $\mathrm{pH}$. Concerning the mineral dissolution occurring during $\mathrm{Pb}$-extraction, it was obvious that no extraction of $\mathrm{Pb}$ could be obtained with these acids without a significant simultaneous extraction of $\mathrm{Mn} . \mathrm{Fe}$ and $\mathrm{Al}$ were dissolved to a smaller extent than $\mathrm{Pb}$. The extraction of $\mathrm{Mn}, \mathrm{Fe}$ and $\mathrm{Al}$ were all above that obtained during steps I-III of sequential extraction, while $\mathrm{Pb}$ was less affected by the organic acids than by the first three steps of sequential extraction.

Remediation experiments: It is well established that the $\mathrm{pH}$ decrease occurring during EDR of fine grained materials suspended in distilled water is a result of water splitting at the surface of the anion-exchange membrane. ${ }^{1,31,32}$ Thus the $\mathrm{pH}$ decrease observed in DW20 (Figure 6) is consistent with previous findings. The phenomenon of water splitting appears because the soil-suspension contains an insufficient amount of mobile anions available for migration across the anion-exchange membrane to compensate for the more abundant mobile cations, which are transferred across the cation-exchange membrane. The slower pH-decrease seen in MA20 and CA20 is likely to result from reduced water-splitting because of the higher concentration of mobile anions (the organic ligands of the acids) in the suspension and the buffer effect of the organic acid itself. The slightly slower pH-decrease in NA20 compared to DW20 could likewise be a result of the nitrate added with the acids.

The less successful remediation obtained in the experiments with malic acid and citric acid could be explained by the observed $\mathrm{pH}$ decrease, which may result in changes in the speciation of $\mathrm{Pb}$ towards less mobile species. Such changes were confirmed by the 
results of the extraction experiments, which showed less mobility at lower $\mathrm{pH}$ when adding organic acids. We modeled the speciation of $\mathrm{Pb}$ in the presence of malate and citrate by use of the programs HYDRA/MEDUSA (Puigdomenech I (http://www.kemi.kth.se/inorg/medusa)) using equilibrium constants for malate from Smith and Martell. ${ }^{33}$ The results are shown in Figures 8 and 9.

The impeded transport of $\mathrm{Pb}$ into electrolytes after addition of the organic acids in MA20 and CA20 could well be explained by the prevalence of uncharged complexes at $\mathrm{pH}$ values below 5. In particular neutral complexes dominate between malate and $\mathrm{Pb}$, which may explain the observed extraction without subsequent transfer of $\mathrm{Pb}$ in MA20. The fact that remediation was not enhanced in MA20N, however, suggests that other mechanisms are dominating, or else the Pb-malate system may not be sufficiently well described. The Pb citrate system is indeed more detailed (Figure 9), and the results of $\mathrm{CA} 20 \mathrm{~N}$ show increased mobilization and transfer of $\mathrm{Pb}$ consistence with the model and the results of the extraction experiments. Still, however, the remediation was seriously impeded compared to the results obtained with distilled water and nitric acid, and the amount of $\mathrm{Pb}$ found in solution in the middle chamber, which may reflect the amount bound to the organic ligands in uncharged complexes, does not account for the difference. Thus the prevalence of neutral complexes cannot alone explain our results.

It was previously observed that EDR of sediments may be less efficient when acids are used as suspending fluid as compared to distilled water. This effect was suggested to arise from the competitive transfer of the ions from the acids in the current field. ${ }^{34}$ An effect, which may also explain the results of the experiments with nitric acid (NA 
20 and NA40) of this work, in which substantially better remediation was obtained at the elevated current density, and supported by the fact that the conductivity was higher when acid was added (Figure 7). When the organic acids were used, the same effect was, however, not observed; hence competitive transfer of the ions from the acids can also not explain the impeded remediation when these acids were used. Overall, the results may be due to a combined effect of size-exclusion, reduced transfer over the ion-exchange membranes of the large organic complexes, prevalence of uncharged complexes and competitive transfer of the ions of the acid; however none of these mechanisms explain the low desorption of $\mathrm{Pb}$ from the soil fines in the experiments with organic acids (Figure 5), and in particular in the experiments with citric acid and potassium citrate. The results of the extraction experiments with citrate (Figure 4a) suggested that adverse effects of the acid addition occur at a citrate concentration above $0.6 \mathrm{M}$. We suggest that precipitation of complexes between $\mathrm{Pb}$ ( $\mathrm{Fe}, \mathrm{Al}$ and $\mathrm{Mn}$ ) and citrate could be the reason for this. It may be that the application of the direct current stimulates the formation of precipitates, which would explain our results.

The overall result of our work is to reject the feasibility of using organic acids as enhancing reagents during EDR in suspension. Thus combination of EDR and heterotrophic leaching does not seem to be a potential method of remediation for contaminated sludge from soil washing. Addition of nitric acid in combination with an increased current density is, in contrast, a qualified suggestion for promotion of EDR of $\mathrm{Pb}$ contaminated soil fines in cases where the removal rate is considered to be more important than the energy expenditure and the acid consumption. 


\section{CONCLUSIONS}

Citric acid, DL-malic acid, gluconic acid, tartaric acid and fumaric acid (0.2M) are able to extract $\mathrm{Pb}$ from contaminated soil fines in excess of the extraction obtained solely by $\mathrm{pH}$-changes at neutral to slightly acidic conditions. The most efficient extraction was obtained with citric and malic acids, with which extraction results were improved when increasing concentrations to 0.5 and $1.0 \mathrm{M}$ respectively. A maximum of $35 \% \mathrm{~Pb}$ was extracted from the present soil. Mn was completely extracted by the organic acids while $\mathrm{Fe}$ and $\mathrm{Al}$ were extracted to a smaller extent than $\mathrm{Pb}$. Electrodialytic remediation of soil-fines in suspension was strongly impeded by the addition of citric acid and malic acid ( $0.5 \mathrm{M}$ and $1.0 \mathrm{M}$ respectively) independently of $\mathrm{pH}$ control of the suspension in regions where the $\mathrm{Pb}$-complexes of these acids ought to be charged. No improvement was obtained when the contact time between reagent and soil prior to application of current was increased or at increased current densities with the organic acids as reagents. The feasibility of combining EDR and heterotrophic leaching of soil fines in suspension is therefore rejected. In contrast, enhancement of EDR with nitric acid showed promising results at current densities increased beyond what is feasible with addition of only distilled water. Thus nitric acid addition is recommended as enhancing reagent in situations, for which a high removal rate is considered more important than energy expenditure and chemical consumption. 


\section{REFERENCES}

1 Jensen PE, Ottosen LM and Ferreira C. Electrodialytic Remediation of PbPolluted Soil Fines $(<63 m \mu)$ in Suspension. Electrochimica Acta 52:34123419, (2007) PubMed .

2 Barona A and Romero F. Fractionation of lead in soils and its influence on the extractive cleaning with EDTA. Environmental Technology; 17(1):63-70, (1996).

3 Kim C and Ong, S.K. Effects of soil properties on lead extraction from leadcontaminated soil using EDTA. Hazardous and Industrial Wastes, Proceedings of the 28th Mid-Atlantic Industrial Waste Conference, Buffalo, Lancaster USA. 425431, (1996)

4 VanBenschoten JE, Matsumoto MR and Young WH. Evaluation and analysis of soil washing for seven lead-contaminated soils. J. Environ. Eng.; 123(3):217-224, (1997).

5 Henneken L, Nortemann B and Hempel DC. Biological degradation of EDTA: Reaction kinetics and technical approach. J. Chem. Tech. Biotechnol. 73(2):144152, (1998).

6 Hinck ML, Ferguson J and Puhaakka J. Resistance of EDTA and DTPA to aerobic biodegradation. Water Sci. Technol. 35(2-3):25-31, (1997). PubMed

7 Reed BE, Berg MT, Thompson JC and Hatfield JH. Chemical Conditioning of Electrode Reservoirs during Electrokinetic Soil Flushing of Pb-Contaminated Silt Loam. J. Environ. Eng. 121(11):805-815, (1995).

8 Wong JSH, Hicks RE and Probstein RF. EDTA-enhanced electroremediation of metal-contaminated soils. J. Hazard. Mat. 55(1-3):61-79, (1997). PubMed

9 Yeung AT, Hsu CN and Menon RM. EDTA-enhanced electrokinetic extraction of lead. J. Geotech. Eng. 122(8):666 -673, (1996). PubMed

10 Wasay SA, Barrington SF and Tokunaga S. Remediation of soils polluted by heavy metals using salts of organic acids and chelating agents. Environ. Tech. 19(4):369-379, (1998).

11 Tandy S, Bossart K, Mueller R, Ritschel J, Hauser L, Schulin R et al. Extraction of heavy metals from soils using biodegradable chelating agents. Environ. Sci. Tech. 38(3):937-944, (2004). PubMed

12 Yang GCC and Lin SL. Removal of lead from a silt loam soil by electrokinetic remediation. J. Hazard. Mat. 58(1-3 ):285-299, (1998). PubMed 
13 Pedersen AJ. Evaluation of assisting agents for electrodialytic removal of $C d, P b$, $\mathrm{Zn}, \mathrm{Cu}$ and Cr from MSWI fly ash. J. Hazard. Mat. B95:185-198, (2002).

14 Pedersen AJ, Ottosen LM and Villumsen A. Electrodialytic removal of heavy metals from municipal solid waste incineration fly ash using ammonium citrate as assisting agent. J. Hazard. Mat. 122(1-2 ):103-109, (2005). PubMed

15 Mohamed AMO. Remediation of heavy metal contaminated soils via integrated electrochemical processes. Waste Manag. 16(8):741-747, (1996). PubMed

16 Viadero RC, Reed BE, Berg M and Ramsey J. A laboratory-scale study of applied voltage on the electrokinetic separation of lead from soils. Sep. Sci. Technol. 33(12):1833-1859, (1998).

17 Burgstaller W and Schinner F. Leaching of Metals with Fungi. J.Biotech. 27(2):91-116, (1993).

18 Groudev SN. Use of Heterotrophic Microorganisms in Mineral Biotechnology. Acta Biotechnol. 7(4):299-306, (1987). PubMed

19 Sayer JA, Raggett SL and Gadd GM. Solubilization of Insoluble MetalCompounds by Soil Fungi - Development of A Screening Method for Solubilizing Ability and Metal Tolerance. Mycol. Res. 99:987-993, (1995) PubMed .

20 Bosecker K. Bioleaching: Metal solubilization by microorganisms. FEMS Microbiol. Rev. 20(3-4):591-604, (1997). PubMed

21 Krebs W, Brombacher C, Bosshard PP, Bachofen Rand Brandl H. Microbial recovery of metals from solids. FEMS Microbiol. Rev. 20(3-4):605-617, (1997). $\underline{\text { PubMed }}$

22 White C, Sayer JA and Gadd GM. Microbial solubilization and immobilization of toxic metals: key biogeochemical processes for treatment of contamination. FEMS Microbiol. Rev. 20(3-4):503-516, (1997). PubMed

23 Bosshard PP, Bachofen R and Brandl H. Metal leaching of fly ash from municipal waste incineration by Aspergillus niger 2. Environ. Sci.Technol. 30(10):30663070, (1996). PubMed

24 Franz A, Burgstaller W and Schinner F. Leaching with PenicilliumSimplicissimum - Influence of Metals and Buffers on Proton Extrusion and CitricAcid Production. Appl. Environ. Microbiol. 57(3):769-774, (1991). PubMed

25 Wenzl R, Burgstaller W and Schinner F. Extraction of zinc, copper, and lead from a filter dust by yeasts. Biorecovery 2:1-14, (1990) PubMed . 
26 Sayer JA, Cotter-Howells JD, Watson C, Hillier S and Gadd GM. Lead mineral transformation by fungi. Current Biol. 9(13):691-694, (1999). PubMed

27 Jackman SA, Maini G, Sharman AK and Knowles CJ. The effects of direct electric current on the viability and metabolism of acidophilic bacteria. Enzyme and Microbial Technol. 24(5-6):316-324, (1999).

28 Dansk Standardiseringsråd. Vandundersøgelse. Metal ved atomabsorptionsspektrofotometri i flamme. Almene principper og retningslinier. Standarder for Vand og Miljø, Fysiske og Kemiske Metoder,Del 1. Holstebro: aoffset: 138-148, (1991).

29 Mester Z, Cremisini C, Ghiara E and Morabito R. Comparison of two sequential extraction procedures for metal fractionation in sediment samples. Anal. Chim. Acta 359(1-2):133-142, (1998).

30 Qin F, Shan XQ and Wei B. Effects of low-molecular-weight organic acids and residence time on desorption of $\mathrm{Cu}, \mathrm{Cd}$, and $\mathrm{Pb}$ from soils. Chemosphere 57(4):253-263, (2004). PubMed

31 Nystroem GM, Ottosen LM and Villumsen A. Acidfication of harbour sediment and removal of heavy metals induced by water splitting in electrodialytic remediation. Sep. Sci. Technol. 40(11):2245-2264, (2005). PubMed

32 Ottosen LM, Hansen HK and Hansen CB. Water splitting at ion-exchange membranes and potential differences in soil during electrodialytic soil remediation. J. Appl. Electrochem. 30(11):1199-1207, (2000).

33 Smith RM and Martell AE. Critical Stability Constants - Other organic ligands. New York: Plenum Press, (1977).

34 Nystroem GM, Pedersen AJ, Ottosen LM and Villumsen A. The use of desorbing agents in electrodialytic remediation of harbour sediment. Sci. Total Environ. 357(1-3):25-37, (2006). PubMed 
Table 1. Experimental plan. The soil-fines were suspended in the reagent during remediation.

\begin{tabular}{|c|c|c|c|}
\hline Expt. & Reagent (pH of reagent) & $\begin{array}{l}\mathbf{J}^{* * *} \\
{[\mathrm{~mA}]}\end{array}$ & $\begin{array}{l}\text { Adjustment of } \mathrm{pH} \\
\text { in II with } \mathrm{NaOH}\end{array}$ \\
\hline DW20 & Distilled Water (pH 6.5) & 20 & - \\
\hline MA20 & $1 \mathrm{M}$ Malic acid (pH 5) & 20 & - \\
\hline CA20 & $0.5 \mathrm{M}$ Citric acid (pH 5) & 20 & - \\
\hline NA20 & $\mathrm{HNO}_{3}(\mathrm{pH} 1.4)$ & 20 & - \\
\hline MA20N* & $1 \mathrm{M}$ Malic acid (pH 7) & 20 & Kept at $6.0( \pm 1.0)$ \\
\hline CA20N* & $0.5 \mathrm{M}$ Citric acid $(\mathrm{pH} 7)$ & 20 & Kept at $6.0( \pm 1.0)$ \\
\hline NA40 & $0.5 \mathrm{M} \mathrm{HNO}_{3}(\mathrm{pH} 0.0)$ & 40 & - \\
\hline MA40N* & 1 M Malic acid (pH 5) & 40 & Kept at $6.0( \pm 1.0)$ \\
\hline CA40N* & $0.5 \mathrm{M}$ Citric acid (pH 5) & 40 & Kept at $6.0( \pm 1.0)$ \\
\hline KC40 & $0.5 \mathrm{M}$ Potassium citrate $(\mathrm{pH} 8.5)$ & 40 & - \\
\hline
\end{tabular}

${ }^{*} \mathrm{~N}=$ neutral conditions in compartment II. The $\mathrm{pH}$-adjustment in II was maintained throughout the experiment .

$* * 20 \mathrm{~mA}$ is equivalent to $0.4 \mathrm{~mA} / \mathrm{cm}^{2} ; 40 \mathrm{~mA}$ is equivalent to $0.8 \mathrm{~mA} / \mathrm{cm}^{2}$. 
Table 2. Characteristics of the soil fines.

\begin{tabular}{lc}
\hline $\mathrm{Pb}[\mathrm{mg} / \mathrm{kg}]$ & $670-1170$ \\
$\mathrm{pH}$ & $7.8+/-0.2$ \\
$\mathrm{CaCO}_{3}[\%]$ & $17.3+/-0.1$ \\
Organic matter $[\%]$ & $7.8+/-0.1$ \\
$\mathrm{CEC}[\mathrm{meq} / 100 \mathrm{~g}]$ & $14.1+/-0.3$ \\
$\mathrm{Fe}[\mathrm{g} / \mathrm{kg}]$ & $27.3+/-0.3$ \\
$\mathrm{Mn}[\mathrm{mg} / \mathrm{kg}]$ & $587+/-26$ \\
$\mathrm{Al}[\mathrm{g} / \mathrm{kg}]$ & $9.9+/-0.2$ \\
\hline
\end{tabular}


Table 3. Experimental performance.

\begin{tabular}{|lcccc|}
\hline Exp. & $\begin{array}{c}\text { Pb Mass } \\
\text { Name }\end{array}$ & $\begin{array}{c}\text { Start Pb } \\
\text { balance [\%] }\end{array}$ & $\begin{array}{c}\text { Final Pb } \\
{[\mathbf{m g} / \mathbf{k g}]}\end{array}$ & $\begin{array}{c}\text { Current } \\
{[\mathbf{m g} / \mathbf{k g}]}\end{array}$ \\
\hline efficiency [\%o] \\
\hline MA20 & 115 & 1170 & 220 & 2.31 \\
\hline CA20 & 86 & 1040 & 400 & 0.20 \\
\hline NA20 & 84 & 1040 & 980 & 0.11 \\
\hline MA20N & 94 & 670 & 48 & 0.34 \\
\hline CA20N & 64 & 1040 & 540 & 0.11 \\
\hline & 96 & 1040 & 560 & 0.16 \\
\hline MA40N & 89 & 670 & 40 & 0.93 \\
\hline CA40N & 69 & 670 & 355 & 0.09 \\
\hline KC40 & 70 & 670 & 515 & 0.17 \\
\hline
\end{tabular}




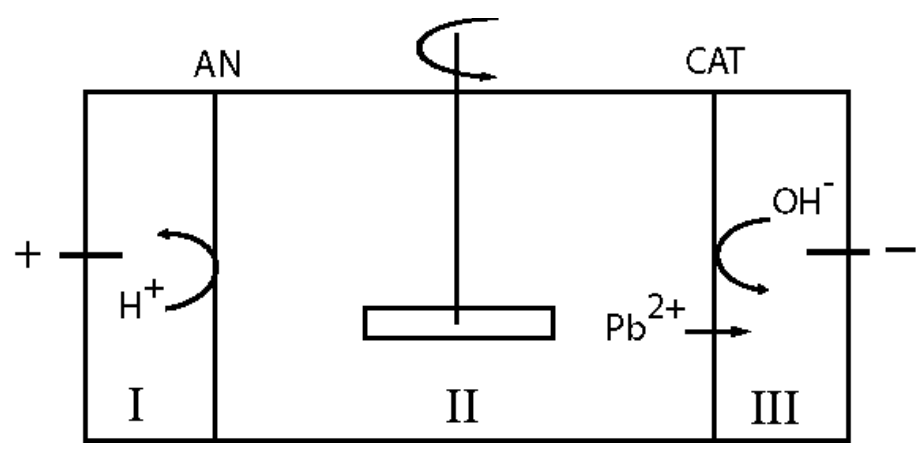

Figure 1. Schematic view of a cell used for experimental EDR of soil fines in suspension. $\mathrm{AN}=$ anion-exchange membrane, $\mathrm{CAT}=$ cation-exchange membrane.

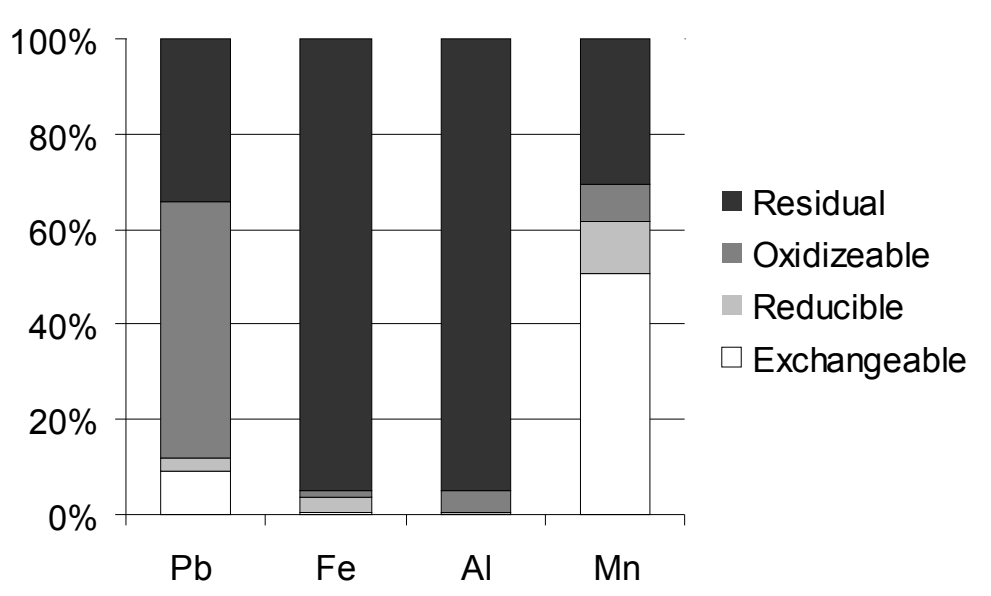


Figure 2. Sequential extraction of $\mathrm{Pb}, \mathrm{Fe}, \mathrm{Al}$ and $\mathrm{Mn}$ from the soil fines.

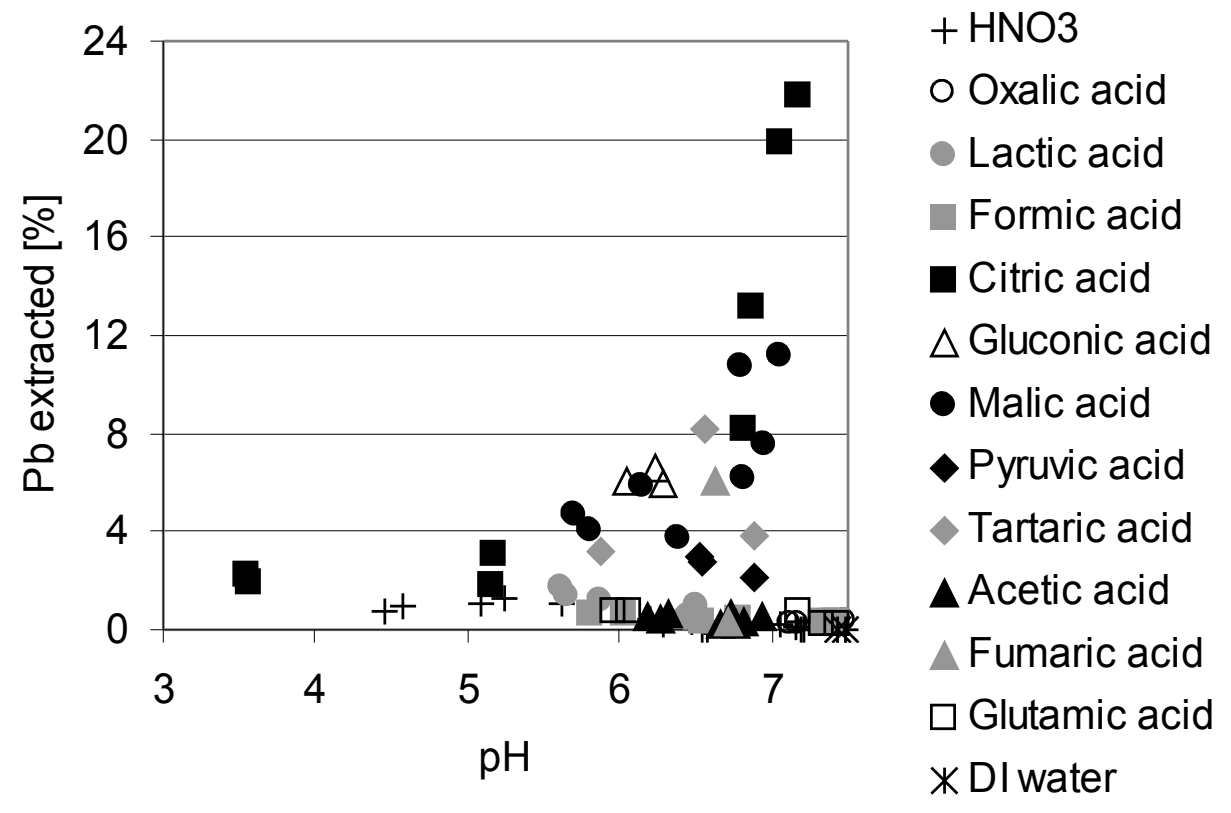

Figure 3. Extraction of $\mathrm{Pb}$ from soil fines with $\mathrm{HNO}_{3}$ and organic acids (0.2M). 

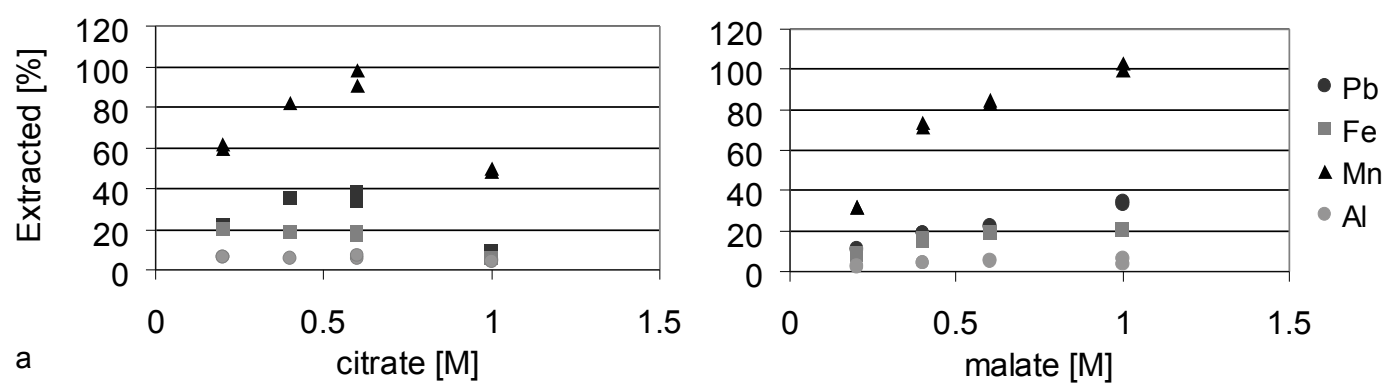

Figure 4. Extraction of $\mathrm{Pb}, \mathrm{Fe}, \mathrm{Mn}$ and $\mathrm{Al}$ from soil fines with a) citric acid (final $\mathrm{pH}$ between 7.1 and 7.7) and b) DL-malic acid (final $\mathrm{pH}$ between 6.8 and 7.2). Results of both duplicate experiments plotted. 


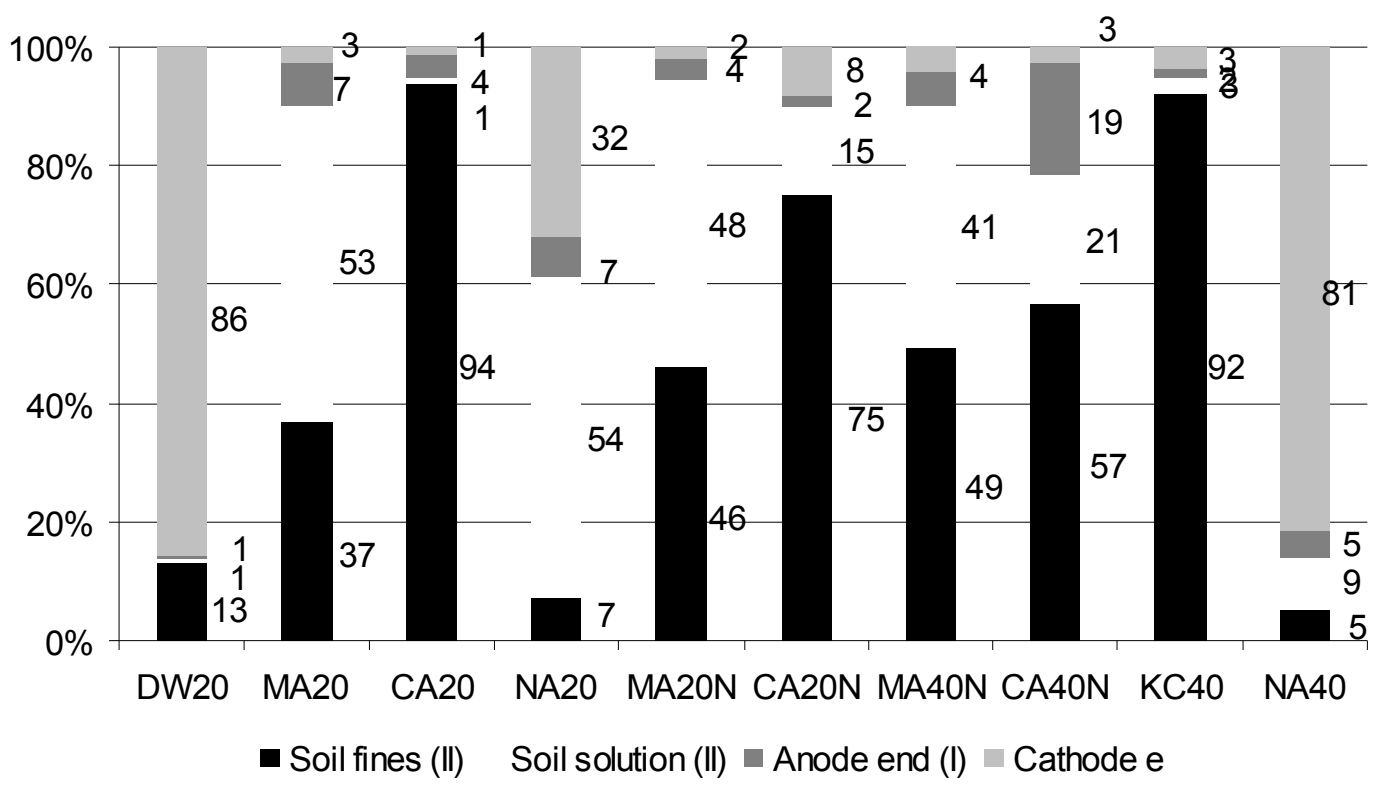

Figure 5. Distribution of $\mathrm{Pb}$ in the compartments of the remediation cell after experimental remediation [\%]. 


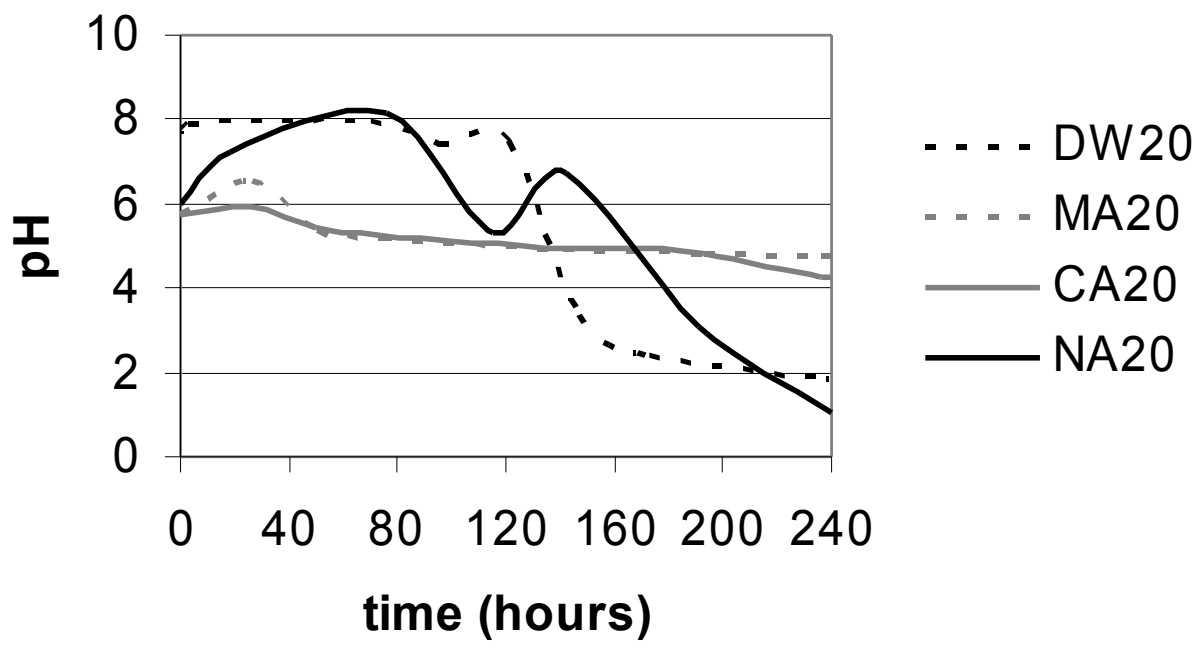

Figure 6. $\mathrm{pH}$ in the soil solution during experimental remediation with distilled water (DW), malic acid (MA), citric acid (CA) and nitric acid (NA) as reagents at 20mA $\left(0.4 \mathrm{~mA} / \mathrm{cm}^{2}\right)$. 


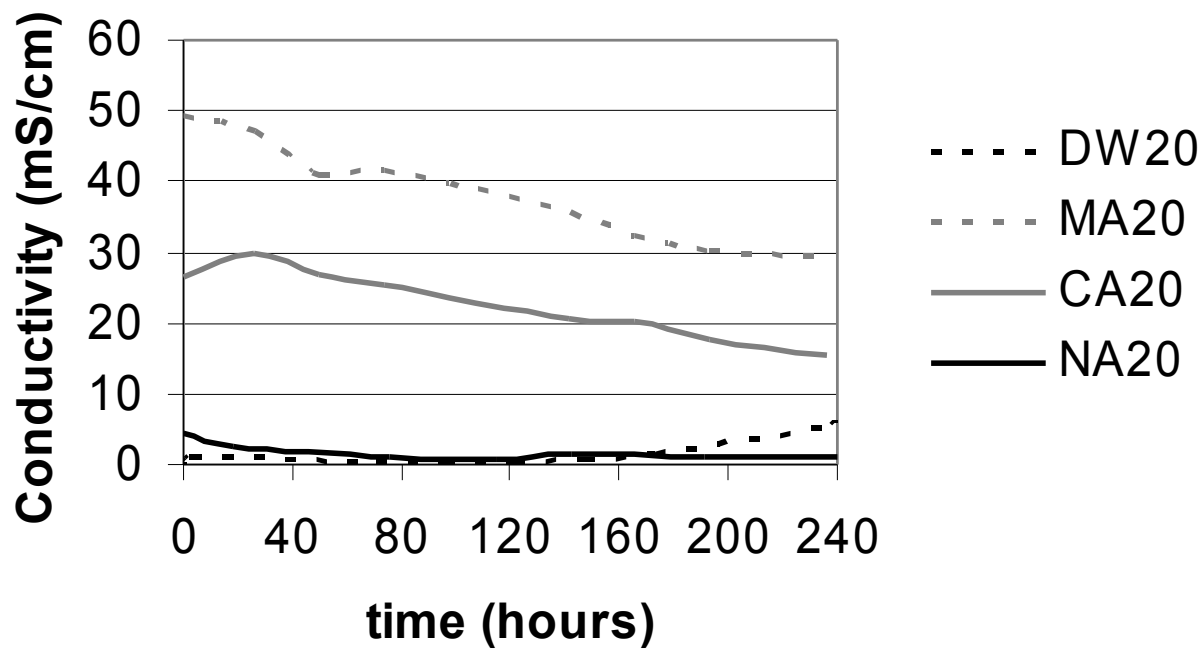

Figure 7. Conductivity in the soil solution during experimental remediation with distilled water (DW), malic acid (MA), citric acid (CA) and nitric acid (NA) as reagents at $20 \mathrm{~mA}\left(0.4 \mathrm{~mA} / \mathrm{cm}^{2}\right)$. 


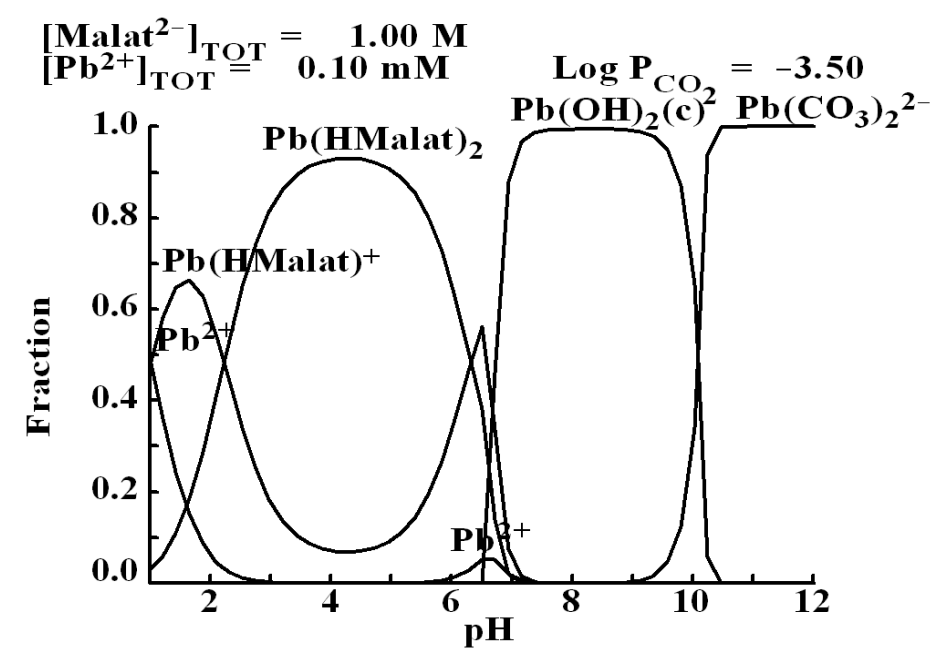

Figure 8. Speciation of $\mathrm{Pb}$ in the presence of excess malate, and carbonate in equilibrium with the atmosphere, as a function of $\mathrm{pH}$. Equilibrium constants for malate form. ${ }^{33}$ 


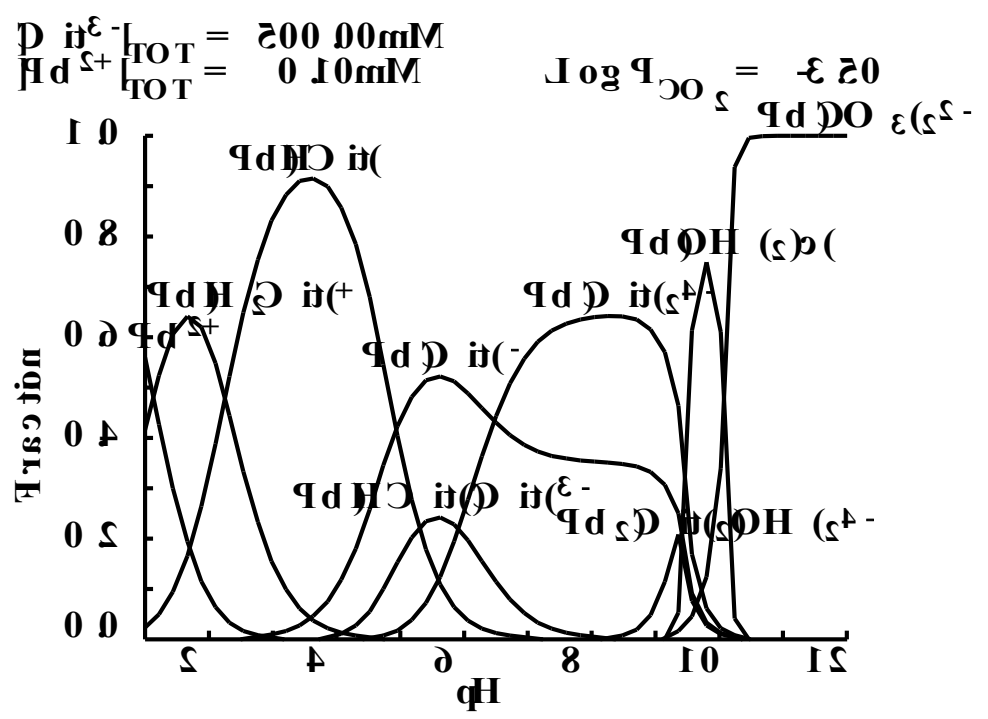

Figure 9. Speciation of $\mathrm{Pb}$ in solution in the presence of excess citrate. 